\title{
Analisis Terhadap Cryptocurrency (Perspektif Mata Uang, Hukum, Ekonomi Dan Syariah)
}

\author{
Afrizal ${ }^{1}$ Marliyah ${ }^{2}$ \\ ${ }^{1}$ Fakultas Ekonomi dan Bisnis Universitas Islam Sumatera Utara \\ Email Corespondent : rizal.loebis74@gmail.com
}

\begin{abstract}
The purpose of this study is to analyze cryptocurrencies based on the characteristics of money, legal perspective, economic perspective and sharia perspective. In this study, the methodology used is descriptive with a qualitative approach. The results show that in this case cryptocurrency can be accepted as money (from the perspective of money characteristics), cryptocurrency does not meet the criteria as a currency (currency perspective), cryptocurrency does not fully fulfill the function of currency (economic perspective), cryptocurrency is not a legal currency in Indonesia. (legal perspective) and the existence of two scholars' opinions (accept and prohibit) regarding cryptocurrency (sharia perspective).
\end{abstract}

Keywords : Cryptocurrency, Bitcoin, Sharia, money, currency, legal perspective, economic perspective, sharia perspective

\footnotetext{
Abstrak : Tujuan dari penelitian ini adalah untuk menganalisis cryptocurrency berdasarkan karakteristik uang, perspektif hukum, perspektif ekonomi dan perspektif syariah. Dalam penelitian ini, metodologi yang digunakan adalah deskriptif dengan pendekatan kualitatif. Hasil penelitian
} 
menunjukkan bahwa dalam ini cryptocurrency dapat diterima sebagai uang (perspektif karakteristik uang), cryptocurrency tidak memenuhi kriteria sebagai mata uang (perspektif mata uang), cryptocurrency tidak sepenuhnya memenuhi fungsi mata uang (perspektif ekonomi), cryptocurrency bukan mata uang yang sah di Indonesia (perpektif hukum) dan adanya dua pendapat ulama (menerima dan melarang) mengenai cryptocurrency (perspektif syariah).

Keywords : Cryptocurrency, Bitcoin, Syariah, uang, mata uang, perspektif hukum, perspektif ekonomi, perspektif syariah

\section{PENDAHULUAN}

Abad ini dapat disebut sebagai abad pasca teknologi informasi di mana lahir pendekatan baru terhadap informasi dan pemrosesan, penggunaan, dan transmisinya. Hari ini informasi tidak hanya menjadi sumber pengetahuan dalam sistem pendidikan, tetapi juga menjadi komoditas. Teknologi informasi saat ini menembus semua aspek aktivitas manusia, termasuk aspek ekonomi.

Seiring berkembangnya teknologi informasi, maka berkembang pula instrument alternatif untuk melakukan pembayaran selain dengan menggunakan uang kartal dan uang giral baik dalam skala domestik maupun internasional. Hal ini memicu berbagai inovasi yang semakin efisien, aman, cepat dan nyaman.

Sebagai bagian dari perkembangan teknologi informasi, instrumen keuangan jenis baru, cryptocurrency telah lahir dan berkembang. Mata uang virtual ini dapat dijadikan sebagai alat transaksi elektronik. Selain itu para pemiliknya juga menggunakan cryptocurrency untuk berinvestasi maupun trading. Kini bertransaksi bisnis dapat dilakukan secara daring tanpa melibatkan pihak penengah seperti bank. Transaksi dilakukan seketika, lintas negara, lintas benua, lebih cepat, lebih mudah, lebih murah, dan lebih terjamin kerahasiaannya (Ausop, 2018)

Cryptocurrency telah menjadi implementasi pertama dari teknologi Blockchain dan potensinya tidak terbatas pada sistem pembayaran saja. Aplikasi terdesentralisasi dibuat pada dasarnya dapat mempengaruhi bidang kehidupan seperti ekonomi, ilmu pengetahuan, pendidikan, seni, budaya dan lain-lain (Shovkhalov \& Idrisov, 2021)

Tahun 2008 merupakan awal era cryptocurrency dengan dirilisnya paper oleh seseorang dengan nama samaran 
Satoshi Nakamoto. Cryptocurrency pertama yang diperkenalkan adalah Bitcoin, dan mulai dioperasikan pada tahun 2009. Karena popularitas Bitcoin, cryptocurrency lainnya menjadi populer di kalangan investor serta konsumen ritel) (Mohd Noh \& Abu Bakar, 2020). Tingginya minat publik, mengakibatkan harga Bitcoin melambung tinggi. Seperti cryptocurrency lainnya membawa dampak negatif ke berbagai sektor. Bank Sentral dan otoritas moneter memperingatkan terhadap risiko terkait dengan cryptocurrency(Robin Sidel, 2013) Awal tahun 2014, Gn. Gox, bursa perdagangan. Bitcoin terbesar dunia runtuh arena kehilangan semua cryptocurrency(Wieczner, 2018). Banyak negara menolak cryptocurrency sebagai mata uang legal karena publisitas negatifnya, yaitu kasus Silk Road pada Juli 2013. Silk Road adalah pasar internet tersembunyi untuk obat-obatan dan layanan ilegal yang telah ditutup oleh Federal Bureau of Investigation (FBI). Pembeli menggunakan Bitcoin untuk bertransaksi dan karena fitur utamanya menjadikan nama pembeli tidak diketahui (anonim).

Kepopuleran Bitcoin kemudian tidak dapat dihindari. Para ahli, pebisnis, maupun lapisan masyarakat lainnya mengkritisi kehadiran cryptocurrency. Beberapa setuju dengan keberadaannya, yang tercatat pada Juli 2010, harga Bitcoin sebesar USD 0,04951, dan mencapai tertinggi pada bulan 17 April 2021 yaitu USD 63.223,88 atau naik 127.699.212,28 persen dari harga pertama yang tercatat.

Terlepas dari prospek yang menjanjikan dengan teknologi futuristik, Bitcoin dan namun tidak sedikit pula yang tidak setuju. Dalam dunia internasional, transaksi Bitcoin masih diperdebatkan. Negara-negara di seluruh dunia telah memberi perhatian terhadap perkembangan Bitcoin dan cryptocurrency lainnya. Reaksi sebagian besar negatif meskipun tingkat reaksi yang berbeda-beda.

Di Indonesia terjadi pro dan kontra terhadap penggunaan mata uang cryptocurrency sebagai alat transaksi pembayaran. Hal ini disebabkan cryptocurrency belum memenuhi kriteria sebagai mata uang yang berlaku di Indonesia seperti dalam UU Nomor 7 Tahun 2011 Tentang Mata Uang.

Dalam perspektif syariah, ada perdebatan tentang keberadaan mata uang virtual. Otoritas keagamaan Pemerintah Turki dan Mufti Besar Mesir telah menyatakan bahwa mata uang virtual adalah haram atau terlarang. Namun pusat fatwa Seminari Islam 
Afrika Selatan telah membolehkan mata uang virtual dalam perdagangan.

Publisitas negatif, isu spekulatif, risiko, legalitas baik dari segi hukum negara maupun Syariah (hukum Islam) yang terkait cryptocurrency menjadi fenomena yang sangat menarik untuk dikaji dan mendorong penulis melakukan penelitian cryptocurrency berdasarkan persfektif uang, perspektif ekonomi, perspektif hukum dan perspektif syariah.

\section{TINJAUAN PUSTAKA}

\section{Pengertian, Karakteristik dan}

\section{Fungsi Uang}

Uang diciptakan untuk memecahkan masalah umat manusia dari sistem barter untuk menukar barang dan jasa di antara mereka. Uang secara umum adalah sesuatu yang dapat dapat diterima secara umum sebagai alat pembayaran yang sah di suatu wilayah tertentu dan sebagai alat pembayaran hutang atau sebagai alat untuk melakukan pembelian barang dan jasa Mujahidin, (Ahmad \& Hassan, 2006)

Dalam Kamus Besar Bahasa Indonesia, uang adalah alat tukar atau standar pengukur nilai (kesatuan hitungan) yang sah, dikeluarkan oleh pemerintah suatu negara berupa kertas, emas, perak, atau logam lain yang dicetak dengan bentuk dan gambar tertentu. Uang juga berarti harta, kekayaan.

Dalam Islam secara etimologi uang berasal dari kata naqdu-nuqud, an-naqdu berarti yang baik dari dirham, menggenggam dirham, an-naqdu juga berarti tunai. Uang dalam literatur fikih disebut dengan tsaman atau nuqud (jamak dari naqd) (Mulvi Aulia, 2021) dan didefinisikan oleh para pakar sebagai berikut: 
1. Menurut Wahbah az Zuhaili (Zuhaili, 2019), mata uang secara umum baik emas maupun perak, atau mata uang yang berlaku seperti potonganpotongan logam berbentuk uang yang disepakati nilainya, atau harganya, termasuk juga uang kertas yang dipakai di zaman ini dapat berfungsi sebagai harga jika difungsikan sebagai alat penukar barang yang dibeli. Beliau juga menambahkan menurut mayoritas ulama Hanafi biasanya harga adalah yang tidak bisa ditentukan wujudnya

2. (Choudhury, 2018) mendefinisikan uang dalam Islam sebagai uang mikro di mana uang hanya digunakan dalam kegiatan ekonomi riil. Fungsi uang yang tidak terkait dengan aktivitas nyata seperti perdagangan mata uang, transaksi derivatif, bahkan bung tarif, tidak termasuk dalam uang mikro

3. Lietaer (2001) dalam (Yuneline, 2019) uang adalah kesepakatan dalam komunitas atau masyarakat untuk digunakan sebagai alat tukar.

4. Menurut Al-Ghazali dalam(Karim, 2001), uang diibaratkan cermin yang tidak mempunyai warna, tetapi dapat merefleksikan semua warna. Uang tidak mempunyai harga, tetapi merefleksikan harga semua barang. Al-Ghazali membolehkan peredaran uang yang sama sekali tidak mengandung emas dan perak asalkan pemerintah menyatakannya sebagai alat bayar resmi.

5. Menurut Abdullah Sulaiman (1996) dalam (Mulvi Aulia, 2021) naqd (uang) adalah segala sesuatu yang menjadi media pertukaran dan diterima secara umum, apa pun bentuk dan dalam kondisi seperti apa pun media tersebut.

Menurut (Supramana, 2014) syarat sebuah benda untuk dijadikan uang adalah benda itu harus diterima secara umum (acceptability), bahan yang dijadikan uang juga harus tahan lama (durability), kualitasnya cenderung sama (uniformity), jumlahnya dapat memenuhi kebutuhan masyarakat serta tidak mudah dipalsukan (scarcity), uang juga harus mudah dibawa (portable), dan mudah dibagi tanpa mengurangi nilai (divisibility), serta memiliki nilai yang cenderung stabil dari waktu ke waktu (stability of value).

Hal ini sejalan dengan pendapat (Meera, 2018), seiring berjalannya waktu, masyarakat menemukan bahwa uang dapat berjalan dengan efisien dan 
efektif jika memenuhi persyaratan yaitu dapat diterima secara umum karena memiliki nilai intrinsik (accepted), mudah dibagi (divisible), kualitasnya cenderung sama (homogeneous), bertahan lama dan tidak mudah rusak (durable), mudah dibawa (mobile), jumlah kecil namun memiliki nilai yang besar (rare), dan bernilai relatif stabil sepanjang waktu (stable value).

Menurut (He et al., 2016), peran ekonomi atau fungsi dari uang adalah sebagai alat penyimpan nilai (store of value), alat pertukaran barang dan jasa (medium of exchange) dan satuan hitung (unit of account).

\section{Sejarah Perkembangan Uang dan}

\section{Mata Uang Fiat}

Uang tidak secara langsung berbentuk seperti apa yang ada saat ini, melainkan telah mengalami evolusi hingga menjadi seperti sekarang (Juhro Solikin M, Syarifuddin Ferry, 2020) Merujuk pada (Mohd Noh \& Abu Bakar, 2020) sejarah perkembangan uang terjadi melalui banyak tahapan dari waktu ke waktu. Tahapan-tahapan tersebut adalah

1. Sistem barter, ketika orang saling bertukar dan berdagang barang dan jasa untuk barang dan jasa lainnya.
2. Sistem uang komoditas, ketika orang menggunakan komoditas seperti gandum, biji-bijian, atau ternak sebagai media pertukaran.

3. Sistem uang logam, ketika orang menggunakan emas dan perak sebagai alat pembayaran. Sistem uang logam berkembang dari waktu ke waktu, dari berbasis satuan berat, berbasis koin hingga berbasis kertas yang $100 \%$ didukung oleh cadangan emas.

4. Uang fiat. Uang fiat telah digunakan selama perang, ketika pemerintah membutuhkan uang untuk membayar perang atau kekurangan uang. Pada tahun 1971, pemerintahan Amerika Serikat di bawah kepemimpinan Presiden Nixon, resmi menghapus uang yang berbasis emas dan digantikan dengan uang fiat yang tidak didukung $100 \%$ emas lagi dan hingga saat ini masih digunakan sebagai alat transaksi (Juhro Solikin M, Syarifuddin Ferry, 2020). Bank sentral mulai mengeluarkan uang kertas dalam berbagai denominasi. Bank sentral memaksa penerimaan uang kertas ini melalui undangundang yang sah, yang mewajibkan semua orang dalam wilayah yurisdiksi untuk menerima uang fiat 
yang tidak dapat dikonversi sebagai pembayaran untuk barang atau jasa dan pelunasan utang. Undangundang tidak mengizinkan orang menolak uang dimaksud sebagai alat pembayaran yang sah. Di dunia sekarang ini,sebagian besar dari semua mata uang adalah mata uang fiat yang tidak dapat dikonversi (Davies, 2002)

Dari penjelasan di atas, kita dapat membedakan antara uang dan mata uang. Uang adalah alat tukar dan penyimpan nilai. Emas dan perak adalah bentuk uang yang optimal, karena mereka memelihara memelihara daya beli dalam jangka waktu lama dengan jumlah yang terbatas. Emas dan perak juga memiliki nilai intrinsik. Mata uang biasanya adalah uang kertas dan koin yang dikeluarkan oleh pemerintah atau bank sentral sebagai alat tukar. Karena mata uang fiat tidak didukung oleh emas, makai ia tidak memiliki nilai intrinsik. Nilainya ditentukan oleh penawaran dan permintaan.

\section{Sejarah Perkembangan Mata}

\section{Uang Virtual}

Perkembangan yang pesat yang berbasis internet dan teknologi seluler mendorong perubahan ekonomi global.
Salah satu perubahan ekonomi yang penting adalah mata uang virtual. Menurut (Mikołajewicz-Woz'Niak \& Scheibe, 2015) uang virtual bukanlah konsep baru. Ini berasal dari konsep komplementer mata uang komplementer, contohnya flyer miles (misalnya Lufthansa), Local Exchange Trading System yang dibuat di Kanada atau Chiemgauer (digunakan di Bavaria). Mata uang semacam ini ditandai dengan kecepatan sirkulasi yang lebih tinggi, karena diciptakan sebagai media pertukaran. Hal yang sama diutarakan oleh (Rahman, 2019)bahwa mata uang digital bukanlah penemuan baru saat ini tetapi sudah ada cukup lama, antara lain dalam bentuk loyalitas atau poin kartu kredit, dan uang dalam video game.

Mata uang virtual telah didefinisikan dalam banyak pandangan oleh para ahli dan lembaga diantaranya :

1. Gugus Tugas Aksi Keuangan dalam (Mikołajewicz-Woz'Niak \& Scheibe, 2015) mendefinisikannya sebagai 'representasi digital baik mata uang virtual (non-fiat) atau uang elektronik (fiat)'. Ini sering digunakan secara bergantian dengan istilah 'mata uang virtual' yang bagaimanapun merupakan bagian dari mata uang digital. 
2. Menurut European Central Bank (2015) mata uang virtual adalah representasi digital dari uang yang tidak dikeluarkan oleh bank sentral dan yang nilainya tidak didukung oleh entitas pemerintah. Dengan cara ini, mata uang virtual menciptakan sistem moneter yang tidak diatur berdasarkan kepercayaan di antara pengguna (Mora et al., 2019)

3. Mengacu kepada (He et al., 2016) mata uang virtual adalah adalah representasi nilai digital, yang dikeluarkan oleh pengembang swasta dan didenominasi dalam unit akun mereka sendiri. Mata uang virtual dapat diperoleh, disimpan, diakses, dan ditransaksikan secara elektronik dan dapat digunakan untuk berbagai keperluan selama pihak-pihak yang bertransaksi setuju untuk menggunakannya. Konsep mata uang virtual mencakup rangkaian "mata uang" yang lebih luas, seperti kupon internet atau seluler dan mil maskapai penerbangangan. Mata uang ini didukung oleh aset seperti emas.

Mata uang virtual dan teknologi blockchain adalah perkembangan pertama dalam teknologi keuangan, yang mempertimbangkan jenis yang sama sekali berbeda mata uang dan sistem perbankan yang berlaku selama ini. Tidak seperti sistem pertukaran konvensional, mata uang virtual seperti cryptocurrency, misal Bitcoin beroperasi melalui teknologi kripto (Jerry Brito, Houman B. Shadab, 2004). Bitcoin yang dioperasikan pada tahun 2009 dan sejumlah cryptocurrency lainnya telah berjalan untuk memenuhi beragam kebutuhan dan tujuan yang berbeda.

Desain utama di balik kesuksesan cryptocurrency adalah teknologi blockchain. Blockchain adalah teknologi terdesentralisasi di mana buku besar digital terdistribusi yang digunakan untuk mencatat secara kronologis dan terbuka atas transaksi antara dua pihak, secara baik, dapat diverifikasi, dan permanen (Hashemi Joo et al., 2020)

Kata "crypto" dalam cryptocurrency mengacu pada enkripsi atau kriptografi yang dibuat oleh instrument dan kemudian ditambahkan ke database blockchain sedangkan "currency" di sini mengacu pada pengakuan sebagai alat tukar di antara penggunanya (Mohd Noh \& Abu Bakar, 2020). Berikut adalah pengertian cryptocurrency menurut beberapa ahli :

1. Menurut (Rosic, 2020) Cryptocurrency adalah media 
pertukaran berbasis internet yang menggunakan fungsi kriptografi untuk melakukan transaksi keuangan. Cryptocurrency memanfaatkan teknologi blockchain untuk mendapatkan desentralisasi, transparansi, dan kekekalan. Fitur paling penting dari cryptocurrency adalah bahwa ia tidak dikendalikan oleh otoritas pusat mana pun, sifat terdesentralisasi dari blockchain membuat cryptocurrency secara teoritis kebal terhadap kendali dan campur tangan pemerintah.

2. Menurut (Hashemi Joo et al., 2020) cryptocurrency adalah sistem pembayaran digital di seluruh dunia yang menjalankan fungsinya secara on line. Berbeda dengan sistem transfer uang lintas batas konvensional yang secara tradisional menggunakan Society for Worldwide Interbank

Financial

Telecommunication (SWIFT) atau Single Euro Payments Area (SEPA) di kawasan Uni Eropa. Keduanya menawarkan keamanan dan keakurat an dalam proses transfer dana. Namun, salah satu kelemahan utama dari kedua sistem ini adalah lamanya proses transaksi, biasanya memakan waktu beberapa hari (hingga lima hari dalam beberapa kasus). Sementara pembayaran digital dapat dilakukan dengan aman dalam satu jam atau bahkan beberapa detik dalam kasus cryptocurrency tertentu, tidak saja dapat digunakan hanya untuk tujuan transaksi bisnis tetapi juga untuk pengiriman uang dan pembayaran mikro.

\section{Ketentuan Mata Uang di Indonesia}

Mata uang di Indonesia diatur oleh Undang-Undang No. 7 Tahun 2011 tentang Mata Uang. Negara Kesatuan Republik Indonesia sebagai suatu negara yang merdeka dan berdaulat memiliki mata uang sebagai salah satu simbol kedaulatan negara yang harus dihormati dan dibanggakan oleh seluruh warga Negara Indonesia. Mata uang diperlukan sebagai alat pembayaran yang sah dalam kegiatan perekonomian nasional dan internasional guna mewujudkan kesejahteraan sosial bagi seluruh rakyat Indonesia.

Alat pembayaran yang sah adalah bentuk uang yang harus diakui oleh pengadilan sebagai pembayaran yang memuaskan untuk setiap utang moneter. Setiap yurisdiksi menentukan apa yang merupakan alat pembayaran yang sah, tetapi pada dasarnya itu adalah segala sesuatu yang ketika ditawarkan ("ditenderkan") dalam pembayaran 
hutang menghapus hutang. Tidak ada kewajiban bagi kreditur untuk menerima pembayaran yang ditenderkan, tetapi tindakan menawarkan pembayaran dengan alat pembayaran yang sah membebaskan hutang.

\section{Mata Uang Dalam Perspektif}

\section{Syariah}

Al-Qur'an menerangkan aturan uang dalam surat An-Nisa' [4:5] sebagai berikut :

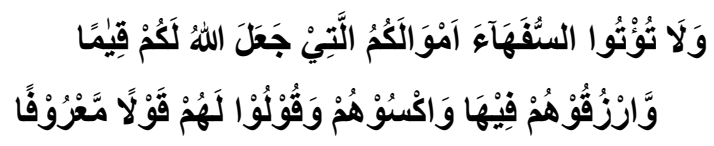

Artinya : "Dan janganlah kamu serahkan kepada orang yang belum sempurna akalnya, harta (mereka yang ada dalam kekuasaan) kamu yang dijadikan Allah sebagai pokok kehidupan. Berilah mereka belanja dan pakaian (dari hasil harta itu) dan ucapkanlah kepada mereka perkataan yang baik.” (QS $4: 5)$

Kata yang digunakan untuk menggambarkan kekayaan dalam ayat ini adalah Qiwam. Ini mengacu pada sesuatu yang dibuat untuk memelihara, mendukung, dan menopang orang lain. Kata ini mencerminkan esensi uang yang sebenarnya; uang adalah sarana ampuh yang telah Allah ciptakan untuk memelihara dan memelihara seluruh sistem duniawi. Ini adalah sarana untuk mencapai tujuan; bukan tujuan itu sendiri. Tujuan akhir dari uang adalah untuk menopang urusan duniawi seseorang untuk memfasilitasi fokus pada akhirat (Faraz Adam, 2018)

Sumber-sumber utama Islam tidak mendefinisikan karakteristik atau kondisi apapun untuk uang. Al-Qur'an dan As-Sunnah hanya mengacu pada uang yang beredar saat itu Dinar (emas) dan Dirham (perak). Dua ayat Al-Qur'an surah Ali 'Imran [3:75] dan surah Yusuf [12:20] menunjukkan bahwa bangsabangsa sebelumnya juga menggunakan Dirham atau koin perak.

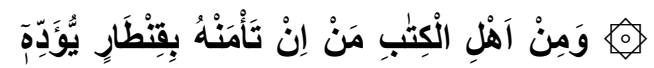

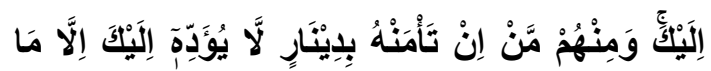

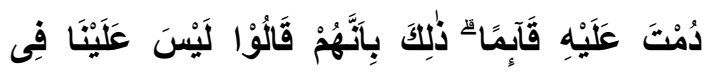

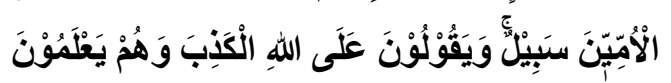

Artinya : "Dan di antara Ahli Kitab ada yang jika engkau percayakan kepadanya harta yang banyak, niscaya dia mengembalikannya kepadamu. Tetapi ada (pula) di antara mereka yang jika engkau percayakan kepadanya satu dinar, dia tidak mengembalikannya kepadamu, kecuali jika engkau selalu menagihnya. Yang demikian itu disebabkan mereka berkata, "Tidak ada dosa bagi kami terhadap orang-orang buta huruf." Mereka mengatakan hal 
yang dusta terhadap Allah, padahal mereka mengetahui.” (QS 3:75)

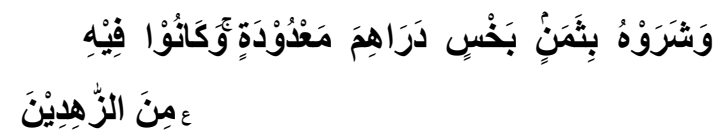

Artinya : "Dan mereka menjualnya (Yusuf) dengan harga rendah, yaitu beberapa dirham saja, sebab mereka tidak tertarik kepadanya." (QS 12:20)

(Haneef \& Barakat, 2006) mengungkapkan beberapa pendapat tentang uang dari para ahli. Salah satu pendapatnya ialah mata uang terbatas pada emas dan perak, sedangkan pendapat yang lain menyatakan sebaliknya bahwa mata uang tidak terbatas pada emas dan perak. Kedua kelompok tersebut memberikan bukti untuk mendukung pandangan masingmasing. Selain itu, dukungan terbesar untuk pendapat kedua berasal dari para srjana kontemporer dan dewan fikih kontemporer. Meskupun kelompok kedua memungkinkan mata uang itu tidak terbatas pada emas dan perak, mereka setuju bahwa logam mulia dapat mewakili nilai dari bahan lain, seperti tembaga. Bukan seperti saat ini yang menggunakan kertas untuk dijadikan sebagai uang (fiat money) yang diciptakan tanpa nilai intrisik untuk mendukungnya.

Beberapa pendapat ulama terkait uang dapat disampaikan sebagai berikut:

1. Menurut Al-Ghazali (w. 505H), uang sebagai nikmat dari Allah SWT, dengan sistem barter dan merupakan sesuatu yang penting dalam peraturan bisnis karena uang merupakan salah satu nikmat dari Allah SWT yang harus ditempatkan sesuai dengan aturan-Nya (Juhro Solikin M, Syarifuddin Ferry, 2020). Lebih jelas lagi menurut Al-Ghazali, dinar dan dirham adalah alat untuk mencapai sesuatu maksud atau suatu perantara saja dan tidak untuk tujuan yang lain. Jadi uang merupakan alat tukar (unit of exchange) dan penengah (intermediary). Al-Ghazali menentang keras perdagangan uang. Allah SWT menciptakan dinar dan dirham untuk diedarkan dan menjadi standar yang adil antara aset yang berbeda. Mereka adalah sarana untuk semua aset lainnya (Faraz Adam, 2018)

2. Menurut Ibnu Taimiyah (w. 728 H) ada dua fungsi utama uang yaitu sebagai alat ukur nilai dan media pertukaran barang dan jasa. Ibnu Taimiyah menentang keras segala bentuk perdagangan uang, karena mengalihkan fungsi uang dari tujuan yang sebenarnya (Juhro Solikin M, 
Syarifuddin Ferry, 2020)

3. Menurut Ibnu Al-Qayyim (w. $751 \mathrm{H}$ ) mengatakan uang tidak pernah mencari untuk dirinya sendiri; melainkan digunakan sebagai sarana untuk mendapatkan komoditas. Ketika uang mulai diperlakukan sebagai komoditas dan menjadi tujuan transaksi, seluruh sistem (ekonomi) akan rusak dan mengalami krisis (Faraz Adam, 2018)

4. Adiwarman Karim menjelaskan konsep uang dalam Islam, uang adalah flow concept, di mana uang harus mengalir dan tidak boleh mengendap dan hanya menimbun di suatu tempat saja. Islam tidak mengenal motif kebutuhan uang untuk spekulasi karena tidak diperbolehkan. Uang adalah barang publik, milik masyarakat karenanya penimbunan uang yang dibiarkan tidak berproduktif berarti mengurangi jumlah uang yang beredar, yang akan berdampak pada kelesuan ekonomi dan stagnansi (terhenti). Uang berfungsi sebagai alat pertukaran, namun uang bukan sebuah komoditi. Dalam istilah ekonomi klasik disebutkan bahwa uang tidak memberikan kegunaan langsung yang artinya jika uang digunakan untuk membeli barang, maka barang itu akan memberikan kegunaan (Karim, 2001)

\section{METODE PENELITIAN}

Metodologi yang digunakan dalam penulisan artikel ini adalah metode deskriptif kualitatif dengan pendekatan normatif yang dilakukan dengan cara mengkaji cryptocurrency dari beberapa perspektif. Penulis mereduksi data-data yang telah diperoleh selama penelitian dengan cara mengkelompokan serta memilih data yang relevan dengan kajian penelitian. Tahapan selanjutnya penulis melakukan penyusunan data-data yang telah dikelompokan sebelumnya dan yang terakhir penulis melakukan verifikasi atau penarikan kesimpulan.

Data penelitian berupa data sekunder yang diperoleh dari artikel jurnal, makalah konferensi, kertas kerja, dan laporan konsultan Syariah terkait cryptocurrency.

\section{Temuan dan Pembahasan}

\section{Cryptocurrency Dalam Perspektif}

\section{Uang}

Pertama makalah ini akan menguji apakah cryptocurrency yang diwakili oleh Bitcoin telah memenuhi persyaratan 
sebagai uang dengan merujuk pada (Supramana, 2014) dan (Meera, 2018) di mana uang harus memenuhi tujuh persyaratan sebagaimana yang telah disebutkan di atas (lihat Tabel 1)

\section{Tabel 1. 1 Perbandingan}

\begin{tabular}{|c|c|c|c|c|}
\hline Persyaratan & Mata Uang Fiat & Emas (komoditas) & Mata Uang Komoditas & s Bitcoin (Cryptocurrency) \\
\hline Nilai intrinsik & Tidak & Ya & Ya & Tidak \\
\hline Dapat dibagi & Ya & Ya & Ya & Ya \\
\hline Homogen & Ya & Ya & $\mathrm{Ya}$ & $\mathrm{Ya}$ \\
\hline Tahan lama & Ya & Ya & Bervariasi & Ya \\
\hline Beredar & Ya & $\mathrm{Ya}$ & Ya & Ya \\
\hline Langka & $\mathrm{Ya}$ & Ya & Tida & Ya \\
\hline Nilai stabil & $\mathrm{Ya}^{*}$ & $\mathrm{Ya}^{8}$ & $\mathrm{Ya}^{*}$ & Tidak \\
\hline
\end{tabular}

Persyaratan Mata Uang

Sumber : (Meera, 2018), (Yuneline, 2019)

Dari Tabel 1, dapat dilihat bahwa Bitcoin memenuhi lima dari tujuh persyaratan sebagai uang. Menurut Meera (2018), benda yang memenuhi lima persyaratan disebut sebagai sebagai good money dan bila memenuhi tujuh persyaratan disebut excellent money. Bitcoin tidak memiliki nilai intrinsik dan tidak bernilai stabil. Sama halnya dengan mata uang fiat, Bitcoin tidak memiliki nilai intrinsik. Meskipun tidak memiliki nilai intrinsik, Bitcoin telah diterima ribuan merchant di seluruh dunia dan masyarakat menerima dan menggunakan Bitcoin sebagai alat alat pembayaran.

Jumlah investor aset cryptocurrency termasuk Bitcoin, Dogecoin, Ethereum dan lain-lain hingga Mei 2021 sudah menembus 6,5 juta pengguna di
Indonesia, dengan nilai transaksi menembus Rp 370 triliun. Besaran angka tersebut sudah melebihi jumlah investor pasar modal di Bursa Efek Indonesia (BEI) kendati jumlah investor pasar modal juga masih terus menunjukkan tren peningkatan. Sampai dengan Februari 2021, BEI mencatat jumlah investor pasar modal mencapai 4,5 juta, naik 16,35\% atau bertambah 634.000 .

Persyaratan nilai stabil mengacu pada fungsi sebagai penyimpan nilai. Semua dari mata uang dapat digunakan sebagai penyimpan nilai, tetapi nilainya dapat menurun karena risiko yang mungkin terjadi. Meskipun harganya sangat fluktuatif, nilai Bitcoin tetap ada selama penggunanya percaya untuk menggunakannya dan menerimanya sebagai alat pembayaran.

Lebih lanjut, (DeVries, 2016) menyatakan bahwa Bitcoin dapat diterima secara luas karena apa yang DeVries gambarkan sebagai "fire triangle". Dimana api membutuhkan bahan bakar, oksigen, dan panas untuk eksis. Bitcoin membutuhkan penerimaan pengguna, penerimaan vendor, dan inovasi. Tanpa ketiga aspek tersebut, Bitcoin mungkin tidak benar-benar menjadi mata uang utama yang dilegitimasi. Bitcoin saat ini mengalami 
peningkatan pengguna, yang mendorong dua aspek lain dari "segitiga api". Adopsi cryptocurrency akan menjadi subjek penting untuk perhatikan di masa depan, karena ini bisa menjadi teknologi yang benar-benar transformatif yang mengubah cara pertukaran uang di seluruh dunia.

Dari penjelasan di atas, Bitcoin dapat diterima sebagai uang, dalam perspektif karakteristik uang.

\section{Cryptocurrency Dalam Perspektif}

\section{Ekonomi}

Dari perspektif ekonomi, makalah ini menguji apakah cryptocurrency memenuhi fungsi sebagai uang. Sebagaimana yang dijelaskan sebelumnya bahwa ada tiga fungsi uang yaitu sebagai alat penyimpan nilai, alat pertukaran barang dan jasa, dan satuan hitung. Saat ini cryptocurrency tidak sepenuhnya memenuhi tiga fungsi uang (lihat Tabel 2).

Tabel 1. 2 Perbandingan Fungsi

\section{Uang}

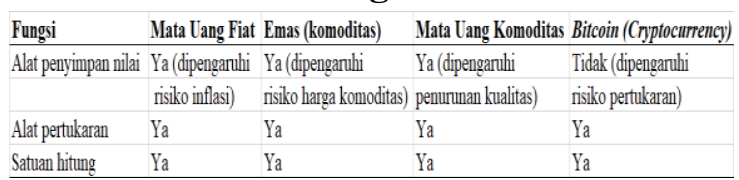

Sumber : (Yuneline, 2019)

Ditinjau dari fungsi pertama sebagai alat penyimpan nilai, volatilitas harga
Bitcoin yang tinggi membatasi kemampuannya untuk berfungsi sebagai penyimpan nilai yang andal. Cryptocurrency memiliki volatilitas yang ekstrem, lonjakan kenaikan dan penurunan harganya sangat cepat, volatiltas yang tinggi merupakan cerminan tingkat risiko yang dihadapi oleh para investor. Volatilitas cryptocurrency hanya dipengaruhi oleh harga masa lalu dan tidak dipengaruhi oleh variabel lain sehingga sulit diprediksi (Warsito \& Robiyanto, 2020)Pergerakan Nilai cryptocurrency sangat tidak stabil, bisa naik turun sangat cepat. Dengan demikian, sulit menganggap Bitcoin sebagai mata uang yang efisien untuk berinvestasi. George Soros dalam (Ferraro et al., 2018) menyatakan bahwa Bitcoin bukanlah sebuah mata uang karena adanya unsur spekulasi disana.

Penulis juga mengamati data historis pergerakan nilai cryptocurrency dalam beberapa tahun terakhir. Harganya sangat tidak stabil dengan volatilitas yang tinggi ditunjukkan oleh grafik harga Bitcoin selama Oktober 2013 - Juli 2021 (Gambar 1). Baik harga dan volatilitas tampaknya tidak terkait dengan ekonomi atau faktor keuangan, membuat mereka sulit untuk dilindung nilai atau diprediksi (Yermack, 2013) 
Per Januari 2017 harga Bitcoin USD 772,66 melonjak tajam per Desember 2017, menjadi USD $17.436,60$ per Bitcoin atau tumbuh sebesar 2.256,70\%. Dua bulan kemudian, per Februari 2018 harganya merosot menjadi USD 9.192,05 per Bitcoin. Dalam tahun 2020, per Desember harga menyentuh di USD 26.975,73 per Bitcoin naik dibandingkan USD 10.201,61per September. Tahun 2021 setelah mencapai puncaknya di April yakni USD 63.223,88 per Bitcoin harga terus merosot menjadi USD 31.640,92 per Bitcoin di bulan Juli.

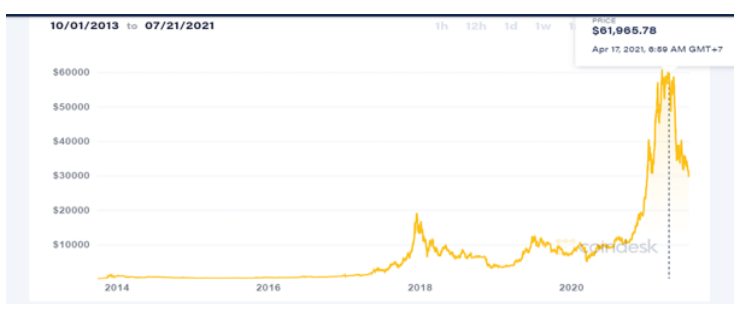

Gambar 1. 1 Harga Bitcoin Oktober 2013- Juli 2021

Sumber :

https://www.coindesk.comb

Para pakar investor menjelaskan bahwa kenapa berinvestasi pada cryptocurrency memiliki risiko sangat tinggi karena pergerakan nilai harga cryptocurrency hanya merupakan gelembung antusiasme sesaat. CEO JP Morgan dan Jamie Dimon pernah menyatakan pendapatnya bahwa Bitcoin (cryptocurrency) lebih buruk daripada tulip bulbs (tulip mania). (Mizner, 2019) Penyataan tentang pergerakan nilai harga cryptocurrency hanya dipengaruhi oleh gelembung antusiasme sesaat ini selaras dengan hasil riset yang telah dilakukan oleh (Liu \& Tsyvinski, 2018) bahwa faktor-faktor yang mempengaruhi pergerakan nilai harga cryptocurrency tidak sama dengan pergerakan saham, mata uang kartal dan logam mulia pada umumnya, pergerakan nilai harga cryptocurrensy lebih dipengaruhi oleh momen-momen tertentu yang mampu menarik perhatian investor. Dengan demikian jelas bahwa Bitcoin tidak memenuhi fungsi penyimpanan nilai.

Fungsi kedua sebagai alat pertukaran. Walaupun cryptocurrency dapat diterima sebagai alat pertukaran namun dengan volume transkasi yang belum besar saat ini dan jaringan penerimaan cryptocurrency yang terbatas secara signifikan membatasi cryptocurrency digunakan sebagai alat tukar. Tanpa status legal yang sah, cryptocurrency diterima hanya jika pihak-pihak yang akan bertransksi setuju untuk menggunakannya. Menurut (He et al., 2016), meskipun pertumbuhan pembayaran berbasis cryptocurrency sangat pesat, jumlah dan volume transaksi di cryptocurrency tetap kecil. Total nilai pasar cryptocurrency saat ini 
adalah sekitar US\$ 7 miliar atau Rp.23,28 triliun, sementara mata uang yang beredar adalah US\$ 2,1 triliun sedangkan pasokan uang USD sebesar (M2) sekitar US\$12 triliun.

Fungsi ketiga sebagai satuan hitung. Merujuk pada Yermack (2013), Bitcoin tampaknya tidak menunjukkan dirinya sebagai satuan hitung atau penyimpan nilai. Namun saat ini, menunjuk pendapat (Yuneline, 2019) ada bukti bahwa cryptocurrency digunakan sebagai satuan hitung. Mekanismenya adalah dengan menilai barang dan jasa berdasarkan kurs cryptocurrency. Misalnya, penjual yang menerima pembayaran cryptocurrency akan memberikan harga dalam mata uang fiat, dengan harga dalam cryptocurrency berdasarkan nilai tukar pada waktu tertentu.

\section{Cryptocurrency Dalam Perspektif}

\section{Hukum}

Meskipun Bitcoin diterima sebagai alat tukar oleh ribuan pedagang di seluruh dunia, beberapa negara telah mengeluarkan peraturan untuk melarang Bitcoin dan cryptocurrency lainnya karena melewati otoritas bank sentral.

China telah menjadi rumah bagi beberapa penambang Bitcoin terbesar. Namun, adalah tindakan ilegal untuk membeli barang di dunia nyata dengan mata uang virtual apa pun. Bank Sentral China telah melarang lembaga keuangan China menggunakan Bitcoin. Selanjutnya, China juga telah melarang perdagangan Bitcoin. Larangan mutlak cryptocurrency berlaku di Aljazair, Bolivia, Mesir, Irak, Maroko, Nepal, Pakistan, dan Uni Emirat Arab. Beberapa bentuk dari larangan implisit berlaku di Bahrain, Bangladesh, Cina, Kolombia, Republik Dominika, Indonesia, Iran, Kuwait, Lesotho, Lithuania, Makau, Oman, Qatar, Arab Saudi dan Taiwan. Ada beberapa negara di mana aktivitas terkait cryptocurrency legal. Ini termasuk Uni Eropa, Amerika Serikat, Meksiko, Jepang, dan Korea Selatan. Negara lain seperti Kanada dan India cryptocurrency tidak ilegal, tetapi ada larangan perbankan (Sarkar, 2020)

Menurut (He et al., 2016) konsep hukum mata uang dikaitkan dengan otoritas pemerintah suatu negara dalam mengatur penerbitan uang kertas dan uang logam. Mata uang mengacu pada satuan hitung dan alat tukar yang diatur oleh undang-undang. Dalam arti sempit, mata uang tersebut mengacu pada uang kertas dan koin yang dikeluarkan oleh otoritas pusat dalam hal ini adalah bank sentral. Mata uang tersebut merupakan alat pembayaran yang sah di bawah hukum negara. Merujuk pada Procter (2012) dalam He et al (2016), konsep 
hukum uang adalah lebih luas dari konsep mata uang. Uang dapat dibuat oleh pihak swasta (tidak hanya uang kertas dan uang logam tetapi juga giro), tetapi harus dalam mata uang yang ditetapkan oleh bank sentral dan harus diterima sebagai media pertukaran di dalam negeri. Oleh karena itu, mengacu pada konsep hukum, Bitcoin tidak diterima sebagai uang. Namun ada beberapa negara yang telah terbuka kehadiran cryptocurrency, antara la(Open Node, n.d.)open:

Jepang. Negara ini dikenal sebagai negara dengan iklim regulasi paling progresif di dunia untuk cryptocurrency. Bisnis pertukaran cryptocurrency diatur dan diharuskan untuk mendapatkan lisensi dari Badan Layanan Keuangan Jepang. Bursa wajib memverifikasi identitas pelanggan, menyimpan catatan transaksi, dan memberi tahu pihak berwenang jika ada aktivitas yang mencurigakan. Jepang secara resmi mengakui Bitcoin sebagai satuan hitung dan alat pembayaran, dan lebih dari 10.000 bisnis - termasuk Rakuten, yang dikenal sebagai Amazon Jepang - saat ini menerima pembayaran Bitcoin.

Korea Selatan. Mirip dengan Jepang, pertukaran Bitcoin di Korea Selatan legal dan beroperasi dalam sistem regulasi yang terdefinisi dengan baik. Korea Selatan adalah pasar terbesar ketiga untuk perdagangan Bitcoin tetapi Bitcoin tidak diakui sebagai alat pembayaran yang sah. Perpajakan secara historis menjadi area abu-abu, tetapi perkembangan terakhir menunjukkan Kementerian Ekonomi dan Keuangan sedang mempertimbangkan pajak 20 persen atas pendapatan yang dihasilkan dari cryptocurrency.

Swiss. Swiss memiliki sikap yang sangat menguntungkan pada Bitcoin sebagai aset. The Swiss Kanton of Zug, khususnya, sedang berusaha untuk memantapkan dirinya sebagai pusat cryptocurrency dan start-up Fintech di Eropa. Swiss mendorong adopsi cryptocurrency dengan pajak rendah pada Bitcoin dan membebaskan penjualan Bitcoin dari pajak Pajak Pertambahan Nilai, tetapi tidak mengklasifikasikan Bitcoin sebagai alat pembayaran yang sah.

Singapura. Saat ini, di Singapura, adalah legal untuk mengoperasikan pertukaran cryptocurrency dan memperdagangkan Bitcoin. Meskipun Bitcoin tidak dianggap sebagai alat pembayaran yang sah, otoritas pajak Singapura telah memutuskan bahwa Bitcoin harus diperlakukan sebagai "barang" dan hanya menerapkan pajak barang dan jasa. Otoritas Moneter Singapura (MAS) telah mengambil pendekatan yang lebih lembut terhadap 
regulasi Bitcoin dan hanya menerapkan kerangka hukum jika memungkinkan. Pada tahun 2018, Wakil Perdana Menteri merilis pernyataan yang mengklarifikasi bahwa cryptocurrency tunduk pada peraturan Anti Money Laundering (AML) and Counter Financing of Terrorism (CFT) sama dengan mata uang tradisional.

Amerika Serikat. Meskipun tidak ada pendekatan hukum tunggal untuk cryptocurrency bisnis cryptocurrency berkembang pesat. Undang-undang yang mengatur pertukaran berbeda-beda di setiap negara bagian, dan otoritas federal berbeda. Jaringan Penegakan Kejahatan Keuangan (FinCEN) tidak menganggap cryptocurrency sebagai alat pembayaran yang sah. Tetapi sejak 2013, mereka telah menganggap cryptocurrency sebagai media pertukaran. Menurut Commodities Futures Trading Commission (CTFC), Bitcoin adalah komoditas terdaftar di bawah Commodity Exchange Act. The Securities and Exchange Commission (SEC) mengindikasikan bahwa mereka tidak menganggap Bitcoin sebagai sekuritas. Sebaliknya, The Internal Revenue Service (IRS) menetapkan bahwa cryptocurrency dianggap sebagai properti, dan telah mengeluarkan panduan pajak yang sesuai. Meskipun tidak ada konsistensi hukum dan peraturan, Bitcoin membuktikan cara yang menarik dan aman bagi bisnis Amerika untuk menerima pembayaran.

Di Indonesia, legalitas cryptocurrency ditentukan oleh UndangUndang No. 7 Tahun 2011 tentang Mata Uang. Dalam Pasal 1 ayat (1) dan ayat (2) dinyatakan :

(1) Mata Uang adalah uang yang dikeluarkan oleh Negara Kesatuan Republik Indonesia yang selanjutnya disebut Rupiah.

(2) Uang adalah alat pembayaran yang sah.

Selanjutnya Pasal 2 ayat (1 ) dan (2) dinyatakan :

(1) Mata Uang Negara Kesatuan Republik Indonesia adalah Rupiah.

(2) Macam Rupiah terdiri atas Rupiah kertas dan Rupiah logam.

Untuk penggunaan Rupiah, dalam Pasal 21 ayat (1) dalam Undangundang dimaksud dinyatakan :

(1) Rupiah wajib digunakan dalam :

a. setiap transaksi yang mempunyai tujuan pembayaran;

b. penyelesaian kewajiban lainnya yang harus dipenuhi dengan uang; dan/atau

c. transaksi keuangan lainnya yang dilakukan di Wilayah Negara Kesatuan Republik Indonesia. 
Ada ketentuan pidana terkait dengan Pasal 21 ayat (1) yang dinyatakan dalam Pasal 33 ayat (1) sebagai berikut :

(1) Setiap orang yang tidak menggunakan Rupiah dalam:

a. setiap transaksi yang mempunyai tujuan pembayaran;

b. penyelesaian kewajiban lainnya yang harus dipenuhi dengan uang; dan/atau

c. transaksi keuangan lainnya

Sebagaimana dimaksud dalam Pasal 21 ayat (1) dipidana dengan pidana kurungan paling lama 1 (satu) tahun dan pidana denda paling banyak Rp200.000.000,00 (dua ratus juta rupiah).

Merujuk pada Undang-Undang tentang Mata Uang di atas, Pemerintah Republik Indonesia tegas menyatakan bahwa satu-satunya pembayaran yang sah di wilayah negara kesatuan Republik Indonesia hanya Rupiah.

Bank Indonesia dalam Pernyataan Pers No: 16/6/DKom tanggal 6 Februari 2014 dengan memperhatikan Undangundang No. 7 Tahun 2011 tentang Mata Uang serta UU No. 23 Tahun 1999 yang kemudian diubah beberapa kali, terakhir dengan Undang-Undang No. 6 Tahun 2009, menyatakan bahwa Bitcoin dan virtual currency lainnya bukan merupakan mata uang atau alat pembayaran yang sah di Indonesia.
Lebih lanjut Bank Indonesia menghimbau masyarakat untuk berhatihati terhadap Bitcoin dan virtual currency lainnya. Segala risiko terkait kepemilikan/penggunaan Bitcoin ditanggung sendiri oleh pemilik/pengguna Bitcoin dan virtual currency lainnya.(Bank Indonesia, n.d.)

Selanjutnya Bank Indonesia mengeluarkan Peraturan BI Nomor 18/40/PBI/2016 tentang Pelaksanaan Proses Transaksi Pembayaran dan Peraturan BI Nomor 19/12/PBI/2017 tentang Penerapan Teknologi Finansial. Dalam Peraturan BI Nomor 18/40/PBI/2016 Pasal 34, dengan jelas disebutkan bahwa Bank Indonesia melarang Penyelenggara Pembayaran Layanan Sistem untuk melakukan pemrosesan transaksi pembayaran menggunakan mata uang virtual. Virtual mata uang yang dimaksud dalam Peraturan BI di atas adalah mata uang digital yang tidak diterbitkan oleh otoritas moneter apa pun dan diperoleh dengan cara menambang. Antara lain Bitcoin, BlackCoin, Dash, Degecoin, Litecoin, Namecoin, Nxt, Peercoin, Primecoin, Ripple dan Ven.

Otoritas Jasa Keuangan (OJK) melarang lembaga jasa keuangan memanfaatkan dan memasarkan mata 
uang digital atau Bitcoin karena tidak adanya legalitas dari Bank Indonesia.

Ada tiga poin yang menyebabkan kenapa Bitcoin di larang di Indonesia:

1. Belum diketahui nilai fundamental atau fungsi dari Bitcoin, berbeda dengan instrumen lainnya yang sudah memiliki fungsi jelas secara fundamental.

2. Kesulitan dalam mencocokkan Bitcoin sebagai mata uang mengingat Undang-Undang (UU) Mata Uang menegaskan bahwa hanya Rupiah yang menjadi alat pembayaran yang sah di Negara Kesatuan Republik Indonesia (NKRI).

3. Tidak ada yang bisa dijadikan jaminan (underlying) yang mendasari Bitcoin sebagaimana produk investasi lainnya (Fransiska, 2018)

Alasan utama pelarangan mata uang virtual oleh Bank Indonesia adalah :

1. Risiko sistem pembayaran dan pengelolaan uang rupiah apabila crypto asset digunakan sebagai alat pembayaran di Indonesia,

2. Risiko capital outflow yang dapat mempengaruhi kebijakan moneter Bank Indonesia

3. Risiko stabilitas sistem keuangan dalam hal transaksi crypto asset semakin membesar dan kompleks serta melibatkan perbankan.
4. Risiko pelanggaran prinsip Anti Pencucian Uang dan Pencegahan Pendanaan Terorisme (APU-PPT)

5. Risiko pelanggaran perlindungan konsumen dan perlindungan data pribadi untuk menerapkan prinsip kehati-hatian, menjaga persaingan usaha, risiko pengawasan, perlindungan konsumen, serta pencegahan tindak pidana, seperti pencucian uang, pendanaan terorisme, dan menjaga kedaulatan rupiah sebagai alat legitimasi pembayaran di Indonesia.

Belakangan Bank Indonesia (BI) akhirnya menjabarkan mata uang digital rupiah atau Central Bank Digital Currency (CBDC) yang akan digunakan di masa depan dalam transaksi keuangan. Produk yang nantinya bernama Digital Rupiah ini merupakan sebuah representasi uang digital yang menjadi simbol kedaulatan negara atau sovereign currency yang diterbitkan bank sentral dan menjadi bagian dari kewajiban moneternya. Central Bank Digital Currency-Digital Rupiah berbeda dengan uang elektronik. Digital Rupiah merupakan yang digital yang diterbitkan bank sentra sehingga merupakan kewajiban bank sentral terhadap pemegangnya. Digital Rupiah juga berbeda dengan cryptocurrency) di mana cryptocurrency tidak diregulasi oleh 
regulator manapun dan sebagian pasokannya terbatas.

\section{Cryptocurrency Dalam Perspektif}

\section{Syariah}

Pertanyaan apakah cryptocurrency sesuai dengan syariah telah didiskusikan oleh para sarjana yang berbeda dengan posisi yang berbeda. Dasar dari diskusi tersebut adalah apakah Bitcoin dan jenis lain dari cryptocurrency adalah komoditas, uang atau mata uang dan aset keuangan. Namun, teknologi blockchain sebagai platform di mana cryptocurrency dibentuk tampaknya tidak menjadi subyek perbedaan pendapat tentang kebolehannya dalam hukum Islam (Mohd Noh \& Abu Bakar, 2020)

Menurut (Sudais, 2018), dalam hukum Islam agar aset dikategorikan halal, harus memenuhi persyaratan. Meskipun cryptocurrency dalam arti harfiah digunakan sebagai media pertukaran, mereka juga memenuhi syarat sebagai aset karena berfungsi sebagai penyimpanan nilai sebagaimana mata uang fiat tradisional. Cryptocurrency dikatakan haram bila mengandung unsur riba, ilegal, ketidapastian (gharar) dan judi (maysir).

Secara umum, ulama memiliki dua pendapat yang berbeda. Kelompok pertama berpendapat bahwa itu adalah diperbolehkan dalam syariat Islam (halal). Kelompok lain berpendapat bahwa cryptocurrency dilarang oleh syariat Islam (haram).

Menurut El Amri dan Mohammed (2019) dan lain-lain dalam Shovkhlaov dan Idrisov (2021), banyak cendekiawan Islam memperbolehkan cryptocurrency. (Faraz Adam, 2018), tidak mengklasifikasikan cryptocurrency sebagai terlarang karena sesuai dengan hukum Islam, Bitcoin dapat disamakan dengan properti, sebagaimana orang melihatnya sebagai nilai tertentu bagi mereka dan memiliki nilai hukum, karena tidak ada kontradiksi nyata dengan syariah.

Merujuk pada Abu Bakar (2017), Pusat Fatwa Seminari Islam Afrika Selatan, Darul Uloom Zakariyya, telah mengambil posisi bahwa Bitcoin pada prinsipnya diperbolehkan. Pertimbangannya adalah bahwa cryptocurrency memenuhi kriteria dan definisi harta (mal) dan uang dengan alasan :

1. Diperlakukan sebagai hal yang berharga di antara orang-orang;

2. Diterima sebagai alat tukar oleh sekelompok orang;

3. Dapat mengukur suatu nilai

4. Memiliki fungsi sebagai satuan hitung 
Dalam Islam, uang dipandang sebagai turunan dari teori nilai dan dengan demikian menjadi konsep nilai intrinsik uang. Sebagaimana dinyatakan dalam Islamic Monetary Theory Value (IMTV), satuan nilai dari uang harus didukung oleh nilai nyata seperti logam berharga (Abdullah, 2016). Para sarjana Muslim sepakat tentang atribut nilai intrinsik uang dan beberapa penelitian mengenai hal ini telah dilakukan (Abdullah, 2016); (Cronin \& Dowd, 2001); (Kiyotaki \& Wright, 1993).

(Muhammad, 2017) menyebutkan bahwa Bitcoin tidak memiliki nilai intrinsik, tidak memiliki bentuk fisik karena hanya ada dalam bentuk digital, pasokannya tidak ditentukan oleh bank sentral mana pun, dan tidak diterbitkan atau dikendalikan oleh perusahaan mana pun. Selanjutnya, dari sisi hukum Islam, Bitcoin dapat memenuhi syarat seperti memiliki nilai, bermanfaat, dapat diidentifikasi, serta dapat ditransfer dan dimiliki, kecuali sebagai komoditas yang memiliki nilai intrinsik. Apapun yang dianggap sebagai komoditas, harus memiliki nilai intrinsik di mana Bitcoin tidak memenuhi persyaratan tersebut. (Hasan, 2011) berpendapat bahwa uang fiat memperoleh nilainya dari penerimaan umum, bukan dari nilai dari bahan apa pembuatannya, dan diakui sebagai alat tukar dalam hukum Islam (Syariah).

Walaupun tidak memiliki nilai intrinsik, cryptocurrency ditambang melalui sistem pengetahuan yang kuat dan keahlian dalam menggunakan teknik enkripsi untuk mengatur dan menghasilkan satuan mata uang, serta memverifikasi pemindahan dana. Protokol ini bisa dibilang lebih kuat daripada proses fiat uang digital (Mohd Noh \& Abu Bakar, 2020)

Dalam analisis langkah lebih lanjut, Muhammad (2017) menyatakan bahwa Bitcoin memenuhi syarat untuk memiliki semua atribut uang seperti satuan hitung, alat tukar, dan penyimpan nilai, dan diterima secara luas dan umum. Ini sesuai dengan pengakuan hukum Islam bahwa adat dan kesepakatan masyarakat dalam mendefinisikan koin emas dan perak sebagai ukuran nilai dan alat tukar, dan yang mata uang modern dapat digunakan untuk membelinya tetapi tidak secara ditangguhkan. Tetapi Bitcoin gagal dalam screen test sebagai alat pembayaran yang sah dan diakui yang diberikan oleh pemerintah manapun. Namun, perlu dicatat juga bahwa pada awal Emas Standar, uang oleh para Pedagang Tukang Emas, bukan pemerintah. Individu, bisnis, dan pemerintah dikendalikan oleh tukang emas. Secara khusus, selama abad 
ketujuh belas dan kedelapan belas, pedagang, bankir, pejabat pemerintah, dan bahkan filsuf menganjurkan dalam banyak tulisan bahwa perekonomian hanya menjadi kaya dan kuat dengan kelebihan emas yang dimilikinya (Salvatore, (2012) dalam Abubakar et al, 2019). Oleh karena itu, pemerintah harus melakukan segala sesuatunya untuk mengendalikan persediaan emas yang besar ini. Itulah asal usul disahkannya uang dalam undang-undang dan disebut sebagai alat pembayaran yang sah. Lebih jauh lagi, pengeluaran perang yang sembrono membuat pemerintah tidak mampu membayar hutang mereka sehingga inilah yang mengharuskan lahirnya uang fiat. Dengan demikian dapat disimpulkan bahwa Bitcoin diperbolehkan dalam syariah dalam pandangan beberapa sarjana karena mata uang fiat yang digunakan saat ini juga tidak memiliki nilai intrinsik.

Selanjutnya, (Ahmad \& Hassan, 2006) berpendapat bahwa dalam Islam, uang diperlakukan sebagai satuan hitung dan sarana pertukaran dan bukan penyimpan nilai, bisa dibilang cryptocurrency memenuhi kriteria ini. Dalam perspektif lain, (Sudais, 2018) melaporkan bahwa analisis komparatif telah dilakukan yang menunjukkan bahwa Bitcoin bebas dari riba, inflasi dan hutang dan dengan demikian bahkan lebih diperbolehkan (halal) daripada uang digital fiat saat ini. Nilai noninflasinya dihasilkan dari kualitas aset yang berharga, tidak seperti mata uang fiat tetapi "ditambang" menggunakan aset bernilai intrinsik yang langka modal manusia. Hal ini sesuai dengan hukum Islam dan diterapkan pada semua bentuk cryptocurrency dan hal-hal lain terkait dalam ekosistemnya seperti opsi, futures, bukti kepemilikan, dan bukti kerja, token dan penawaran umum perdana.

Namun, beberapa cryptocurrency juga didukung oleh aset nyata, seperti emas. Ini dikeluarkan oleh pihak swasta. Salah satu cryptocurrency tersebut adalah OneGram yang dikeluarkan di Dubai baru-baru ini dan dapat diterima sebagai cryptocurrency Islam. Ini karena OneGram memiliki semua karakteristik uang yang dibutuhkan dibandingkan dengan Bitcoin, termasuk memiliki nilai intrinsik, penerbit yang diketahui, memiliki administrator, auditor, dan penjamin (Meera, 2018)

Tabel 3 di bawah ini merangkum evaluasi Bitcoin terhadap mata uang fiat dan cryptocurrency yang didukung asset dari perspektif Islam. 


\begin{tabular}{|c|c|c|c|}
\hline \multirow{2}{*}{ Fitur } & \multirow{2}{*}{ Mata Uang Fiat } & \multicolumn{2}{|c|}{ Bitcoin \& Cryptocurreny $\quad$ Cryptocurreny } \\
\hline & & yang tidak didukung Aset & t yang didukung Aset (misal emas) \\
\hline Tingkat judi (maysir) & Medium & Tinggi & Rendah \\
\hline Tingkat ketidakpastian (gharar) & Medium & Tinggi & Rendah \\
\hline Islamic Money? (misal kontribusi & i Tidak & Tidak & Ya \\
\hline terhadap Maqasid al-Shariah) & & & \\
\hline
\end{tabular}

Gambar 1. 2 Perbandingan Mata Uang Fiat dan Cryptocurrency Dalam Perspektif Islam

Sumber : (Meera, 2018)

Dari Tabel 3 di atas menunjukkan bahwa cryptocurrency juga didukung oleh aset nyata, seperti emas memiliki tingkat perjudian dan tingkat ketidakpastian yang rendah serta berkontribusi terhadap maqasid alshariah. Apakah ada yang namanya "uang Islam"? Ketika kita mengatakan sesuatu adalah 'Islami', itu berarti sesuatu itu berkontribusi pada pencapaian maqashid al syariah. Oleh karena itu ekonomi Islam, perbankan dan keuangan Islam harus berkontribusi terhadap pencapaian maqashid al syariah. Oleh karena itu, jika ada uang atau sistem pembayaran yang dapat membantu kita dalam mencapai maqasid al-syariah, kita dapat menyebutnya sebagai uang dan sistem pembayaran Islam dan sebaliknya (Meera, 2018)

Dalam pandangan ulama yang melarang cryptocurrency, (Mohd Noh \& Abu Bakar, 2020) menyatakan ulama Syariah, seperti Mufti Besar Mesir, Pemerintah Turki, Pusat Fatwa Palestina dan Syeikh Haitam dari Inggris telah menyatakan bahwa cryptocurrency dilarang. Alasan utama pernyataan mereka adalah sebagai berikut:

1. Cryptocurrency mudah digunakan untuk kegiatan ilegal. Pengguna menggunakannya untuk menghindari dan bersembunyi dari pemerintah atau pihak berwenang.

2. Cryptocurency tidak berwujud dan hanya tersedia di internet.

3. Cryptocurrency tidak memiliki otoritas pusat untuk memantau dan mengaudit sistemnya, Ia menghancurkan kontrol bank sentral dan pemerintah dalam memantau dan mengendalikan sistem keuangan.

4. Cryptocurrency memungkinkan pencucian uang dan penipuan

5. Transaksi cryptocurrency terbuka untuk spekulasi (gharar).

6. Penerbit cryptocurrency tidak diketahui baik pemerintah maupun pusat otoritas ada di belakangnya. Ia hadir tanpa adanya otoritas dan sistem pemantauan dan oleh karena itu tidak dapat dipercaya dan tidak bisa diandalkan.

7. Cryptocurrency termasuk jenis perjudian. Orang mengeluarkan banyak uang untuk membeli cryptocurrency tanpa jaminan apakah mereka akan berhasil atau tidak. Para penambang cryptocurrency didasarkan pada permainan zero sum. Jika para penambang berhasil 
memecahkan teka-teki matematika, mereka mendapatkan uang, jika tidak mereka tidak mendapatkan apaapa.

Menunjuk (Meera, 2018), gharar di sini menyangkut hal-hal seperti (1) Tidak ada yang tahu pasti siapa di balik perangkat lunak Bitcoin sehingga tidak ada yang benar-benar bertanggung jawab atas Bitcoin atau sistem secara keseluruhan; (2) Bagaimana seseorang mengetahui atau mengonfirmasi bahwa sistem bitcoin tidak memberi imbalan yang mahal kepada penciptanya, katakanlah secara berkala memberikan ribuan bitcoin gratis kepada penciptanya; (3) Tidak ada orang yang benar-benar mengaudit sistem untuk kepentingan semua orang, meskipun sebagian besar pengguna Bitcoin tampaknya percaya pada keaslian dan transparansi sistem. (4) Nilai Bitcoin sangat fluktuatif. Ada kemungkinan nilai Bitcoin dimanipulasi menjadi gelembung. Oleh karena itu, Bank Dunia menyebut Bitcoin sebagai skema Ponzi; (5) Bitcoin tidak memiliki nilai intrinsik dan menjamurnya banyak cryptocurrency pasti menciptakan inflasi dalam skala global; (6) Tidak ada kepastian penyelesaian masalah jika dompet elektronik Bitcoin seseorang diretas dan dicuri. Ada beberapa kasus seperti itu di Korea Selatan dan Jepang akhir-akhir ini.
Majelis Ulama Indonesia memberi penjelasan mengenai Bitcoin dalam sebelas poin yang diantaranya mengatakan bahwa Bitcoin pada beberapa negara digolongkan sebagai mata uang asing. Umumnya tidak diakui otoritas dan regulator sebagai mata uang dan alat tukar resmi karena tidak merepresentasikan nilai aset. Transaksi Bitcoin mirip Forex, maka tradingnya kental rasa spekulatif. Bitcoin sebagai investasi lebih dekat pada gharar (spekulasi yang merugikan orang lain). Keberadaannya tak ada asset pendukungnya, harga tak bisa dikontrol dan keberadaannya tak ada yang menjamin secara resmi sehingga kemungkinan besar banyak spekulasi ialah haram. Bitcoin hukumnya adalah mubah sebagai alat tukar bagi yang berkenan untuk menggunakannya dan mengakuinya. Namun Bitcoin sebagai investasi hukumnya adalah haram karena hanya alat spekulasi bukan untuk investasi, hanya alat permainan untung rugi bukan bisnis yang menghasilkan. hanya alat permainan untung rugi bukan bisnis yang menghasilkan.

Dari fatwa tersebut di atas dan pandangan para ulama dan ahli sehubungan dengan larangan cryptocurrency, ada beberapa alasan umum dari larangan tersebut yaitu status sebagai alat pembayaran yang sah, 
penerbit Bitcoin dan cryptocurrency lainnya tidak diketahui, tidak adanya otoritas pusat atau pemerintah dibelakangnya, tidak stabil dan tingginya spekulasi, dan Bitcoin dan cryptocurrency lainnya mudah digunakan dalam pencucian uang dan tujuan ilegal lainnya.

\section{PENUTUP}

\section{Kesimpulan}

1. Ada persyaratan yang harus dipenuhi cryptocurrency berkaitan dengan karakteristik mata uang, yaitu memiliki nilai intrinsik (accepted), mudah dibagi (divisible), kualitasnya cenderung sama (homogeneous), bertahan lama dan tidak mudah rusak (durable), mudah dibawa (mobile), berjumlah kecil namun memiliki nilai yang besar (rare), dan bernilai relatif stabil sepanjang waktu (stable value). Dalam hal ini cryptocurrency memenuhi lima persyaratan sehingga dapat diterima sebagai mata uang.
2. Mata uang yang sah diterbitkan oleh otoritas moneter (bank sentral) sedangkan cryptocurrency tidak diterbitkan oleh bank sentral maka dari perspektif hukum, cryptocurrency tidak memenuhi kriteria sebagai mata uang.

3. Dari perspektif ekonomi, mata uang harus memiliki tiga fungsi sebagai alat tukar, satuan hitung dan penyimpan nilai. Cryptocurrency tidak sepenuhnya memenuhi tiga fungsi mata uang karena volatilitas harga yang tinggi.

4. Dari perspektif syariah, ada dua kelompok ulama dan sarjana Islam yang berbeda pandangan terhadap kehadiran cryptocurrency. Satu kelompok membolehkan cryptocurrency dan kelompok yang lain melarangnya. 


\section{REFERENSI}

Abdullah, A. (2016). An Islamic monetary theory of value and equation of exchange: evidence from Egypt (696-1517). Humanomics, 32(2), 121-150. https://doi.org/10.1108/H-12-2015-0090

Ahmad, A. U. F., \& Hassan, M. K. (2006). The Time Value of Money Concept in Islamic Finance. American Journal of Islamic Social Sciences, 23(1), 66-89. https://doi.org/10.35632/ajiss.v23i1.436

Ausop, A. Z. \& E. S. N. A. (2018). TEKNOLOGI CRYPTOCURRENCY BITCOIN UNTUK INVESTASI DAN TRANSAKSI BISNIS MENURUT SYARIAT ISLAM THE PERSPECTIVE OF ISLAMIC SYARIAT ON CRYPTOCURRENCY TECHNOLOGY OF BITCOIN FOR INVESTMENT AND BUSINESS TRANSACTIONS. Sosioteknologi, 17(1), 74-92.

Bank Indonesia. (n.d.). PERNYATAAN BANK INDONESIA TERKAIT BITCOIN DAN VIRTUAL CURRENCY LAINNYA. Retrieved July 22, 2021, from https://www.bi.go.id/id/publikasi/ruangmedia/news-release/Pages/sp_160614.aspx

Choudhury, M. A. (2018). Comparative Islamic Perspectives in Money, Monetary Policy, and Social Wellbeing. Journal of Economic Cooperation and Development, 1, 143-162.

Cronin, D., \& Dowd, K. (2001). F UTURE? The Monetary Base as the Lever of Monetary Policy. University Business, 21(2), 227-244.

Davies, G. (2002). History of Money From Ancient to The Present Day. University of Wales Press.

DeVries, P. (2016). An Analysis of Cryptocurrency, Bitcoin, and the Future. International Journal of Business Management and Commerce, 1(2), 1-9.

Faraz Adam, M. (2018). Bitcoin: Shariah Compliant? Amanah Finance Consultancy, 1-54. www.afinance.org

Ferraro, P., King, C., \& Shorten, R. (2018). Distributed ledger technology for smart cities, the sharing economy, and social compliance. IEEE Access, 6, 62728-62746. https://doi.org/10.1109/ACCESS.2018.2876766

Fransiska, A. (2018). 6 Risiko Investasi Bitcoin yang Perlu Investor Pahami Supaya Tidak Buntung. https://www.finansialku.com/6-risiko-investasi-bitcoin-yang-perlu-investor-pahami/

Haneef, M. A., \& Barakat, E. R. (2006). Must Money Be Limited to Only Gold and Silver ?: Journal of King Abdulaziz University-Islamic Economics, 19(1), 21-34.

Hasan, Z. (2011). Money creation and control from Islamic perspective Zubair. NCEIF The Global University of Islamic Finance, 2116, 0-33.

Hashemi Joo, M., Nishikawa, Y., \& Dandapani, K. (2020). Cryptocurrency, a successful application of blockchain technology. Managerial Finance, 46(6), 715-733. https://doi.org/10.1108/MF-09-20180451

He, D., Habermeier, K., Leckow, R., Haksar, V., Almeida, Y., Kashima, M., Kyriakos-Saad, N., Oura, H., Sedik, T. S., Stetsenko, N., \& Verdugo-Yepes. (2016). International Monetary Fund: Virtual Currencies and Beyond: Initial Considerations. IMF Staff Discussion Note, SDN/16/03. https://www.imf.org/external/pubs/ft/sdn/2016/sdn1603.pdf

Jerry Brito, Houman B. Shadab, A. C. (2004). Bitcoin Financial Regulation: Securities, Derivatives, 
Prediction Markets, and Gambling. THE COLUMBIA SCIENCE \& TECHNOLOGY LAW REVIEW, $X V I$. http://www.stlr.org/cite.cgi?volume $=16 \&$

Juhro Solikin M, Syarifuddin Ferry, S. A. (2020). Ekonomi Moneter Islam Suatu Pengantar (1st ed.). PT. Raja Grafindo Persada.

Karim, A. A. (2001). Ekonomi Islam Suatu Kajian Kontemporer. Gema Insani Pers.

Kiyotaki, N., \& Wright, R. (1993). A search-theoretic approach to monetary economics. American Economic Review, 83(1), 63-77. https://doi.org/10.2307/2117496

Liu, Y., \& Tsyvinski, A. (2018). Risks and returns of cryptocurrency. Working paper. NBER Working Paper, 24877, 1-68. http://www.nber.org/papers/w24877

Meera, A. K. M. (2018). Cryptocurrencies From Islamic Perspectives: The Case Of Bitcoin. Buletin Ekonomi Moneter Dan Perbankan, 20(4), 443-460. https://doi.org/10.21098/bemp.v20i4.902

Mikołajewicz-Woz'Niak, A., \& Scheibe, A. (2015). Virtual currency schemes - The future of financial services. Foresight, 17(4), 365-377. https://doi.org/10.1108/FS-04-2014-0021

Mizner, W. (2019). Chapter 10 Engaging in Gambling Disguised as Investing - 02-26-18. Navigating the Investment Minefiel, 159-175.

Mohd Noh, M. S., \& Abu Bakar, M. S. (2020). Cryptocurrency as A Main Currency: A Maqasidic Approach. Al-Uqud : Journal of Islamic Economics, 4(1), 115-132. https://doi.org/10.26740/aluqud.v4n1.p115-132

Mora, H., López, F. A. P., Tello, J. C. M., \& Morales, M. R. (2019). Virtual Currencies in Modern Societies: Challenges and Opportunities. In Politics and Technology in the Post-Truth Era. https://doi.org/10.1108/978-1-78756-983-620191012

Muhammad, M. (2017). Sharī a analysis of crypto currency: Bitcoin. ISRA Paper. Sharī'a Fintech Forum.

Mulvi Aulia. (2021). Uang Elektronik, Uang Digital (Cryptocurrency) Dan Fatwa Dsn-Mui No.116 Tentang Uang Elektronik. Al-Mizan: Jurnal Hukum Dan Ekonomi Islam, 5(1), 15-32. https://doi.org/10.33511/almizan.v5n1.15-32

Open Node. (n.d.). Bitcoin Regulation: Which Countries are Bitcoin-Friendly. Retrieved July 26, 2021, from https://www.opennode.com/blog/bitcoin-regulation-which-countries-are-bitcoin-friendly/

Rahman, S. F. H. S. A. (2019). Regulating Digital Currency: Taming the Unruly. Islamic Finance Law and Practice in Malaysia, 265-280. https://doi.org/10.1108/978-1-78973-545-120191021

Robin Sidel, C. D. and W. H. (2013). Central Banks Warn of Bitcoin Risks China, France Issue Stark Reports; Beijing Bars Financial Institutions From Offering Related Services. https://www.wsj.com/articles/china-central-bank-warns-of-bitcoin-risks-1386234633.

Rosic, A. (2020). What is Cryptocurrency? [Everything You Need To Know!]. https://blockgeeks.com/guides/what-is-cryptocurrency/

Sarkar, S. R. C. and P. (2020). Cryptocurrency: Further Issues, An Introduction to Algorithmic Finance, Algorithmic Trading and Blockchain. Emerald Group Publishing.

Shovkhalov, S., \& Idrisov, H. (2021). Economic and Legal Analysis of Cryptocurrency: Scientific Views from Russia and the Muslim World. Laws, 10(2), 32. https://doi.org/10.3390/laws10020032

Sudais, A. (2018). The halal and haram aspect of cryptocurrencies in Islam. Journal of Islamic Banking and Finance, 35(2), 91-101. https://circlehinternational.org/uploads/reports/report- 
$15810714925 \mathrm{e} 3 \mathrm{~d} 3 \mathrm{c} 84 \mathrm{~b} 2 \mathrm{~d} 1 \mathrm{e} . \mathrm{pdf} \#$ page $=90$

Supramana. (2014). Hukum Uang di Indonesia. Gramata Publishing.

Warsito, O. L. D., \& Robiyanto, R. (2020). Analisis Volatilitas Cryptocurrency, Emas, Dollar, Dan Indeks Harga Saham (Ihsg). International Journal of Social Science and Business, 4(1), 40-46. https://doi.org/10.23887/ijssb.v4i1.23887

Wieczner, J. (2018). \$1 Billion Bitcoins Lost in Mt. Gox Hack to Be Returned to Victims.

Yermack, D. (2013). Is Bitcoin a Real Currency? SSRN Electronic Journal. https://doi.org/10.2139/ssrn.2361599

Yuneline, M. H. (2019). Analysis of cryptocurrency's characteristics in four perspectives. Journal of Asian Business and Economic Studies, 26(2), 206-219. https://doi.org/10.1108/jabes-12-2018-0107

Zuhaili, W. (2019). Fiqih Islam Wa Adillatuhu . Jilid 5 Terj. Abdul Hayyie al Kattani. Gema Insani Pers. https://www.idxchannel.com/economics/menilik-bitcoin-haram-atau-halal-ini-11-catatan-mui. Diakses 26 Juli 2021.

https://www.cnbcindonesia.com/tech/20210531072626-37-249403/jreeng-ini-dia-gambaran-uangdigital-bank-indonesia. Diakses 26 Juli 2021.

https://nasional.kontan.co.id/news/bi-tegaskan-minimal-10-tahun-ke-depan-cryptocurrency-tidakboleh-jadi-alat-pembayaran. Diakses tanggal 22 Juli 2021.

https://www.idxchannel.com/market-news/crypto-ancur-lebur-rp7000-triliun-hilang-dari-pasar. Diakses tanggal 21 Juli 2021. 